\title{
ANALISIS LINGKUNGAN STRATEGIK DALAM CORAK PENYELENGGARAAN PENDIDIKAN ISLAM
}

\author{
Muhamad Khoirul Umam* \\ khoirul_umam2426@yahoo.co.id
}

\begin{abstract}
The writing of this article is grounded by observations and simultaneous assessments of the external and internal environments of educational institutions allowing education managers to be able to identify the different types of opportunities available to successfully formulate and implement various educational plans. This comprehensive design can be done through a process of action known as a strategic environmental analysis. Strategic concept is more effective in allocating existing resources in achieving educational goals. The existence of the implementation of Islamic Education will be a means, the media in the distribution of vision and mission in addition to implications on improving the quality of faith, taqwa, even faith (leader) for the devout. Environmental analysis is a stakeholder analysis, a very important instrument for understanding the social and institutional context of a program / project activity. This instrument is used to identify stakeholder interests, interests, and influence on ongoing program / project activities.
\end{abstract}

Keywords : Lingkungan Strategik, Corak Pendidikan Islam.

\section{Pendahuluan}

Pendidikan yang diterapkan di lingkungan internal sistem kelembagaan hanyalah sebagian dari tanggung jawab kepala lembaga pendidikan sebagai manajer pendidikan Para pengelola lembaga pendidikan merupakan eksekutif modern saat ini harus mampu mengamati dan merespon segenap tantangan yang dimunculkan oleh lingkungan eksternal baik yang dekat maupun yang jauh. Lingkungan eksternal dekat adalah lingkungan yang mempunyai pengaruh langsung pada operasional lembaga pendidikan, seperti berbagai potensi dan keadaan dalam bidang pendidikan yang menjadi konsentrasi usaha sekolah itu sendiri, situasi persaingan, situasi pelanggan pendidikan, dan pengguna lulusan. Kesemuanya berpengaruh pada penentuan strategi yang diperkirakan mendukung penyelenggaraan pendidikan mencapai tujuannya. Lingkungan eksternal yang jauh adalah berbagai kekuatan dan kondisi yang muncul di luar lingkungan eksternal yang dekat meliputi keadaan sosial ekonomi, politik, keamanan nasional, perkembangan teknologi, dan tantangan global. Secara tidak langsung berpengaruh terhadap penyelenggaraan sistem pendidikan di suatu lembaga pendidikan.

Faktor lingkungan internal dan eksternal perlu diantisipasi, dipantau, dinilai, dan disertakan sedemikian rupa ke dalam proses pengambilan keputusan eksekutif. Para pengambil keputusan, termasuk di dalamnya kepala lembaga maupun pengelola pendidikan lainnya seringkali terpaksa mengalahkan tuntutan kegiatan interen dan eksteren lembaga pendidikan demi melayani bermacam kepentingan seperti urusan rutin, dinas, bekerja harus selalu di bawah petunjuk atau pedoman kerja yang ditetapkan oleh birokrasi tanpa mempertimbangkan kebutuhan eksternal organisasi yang terus berubah, sehingga proses pengambilan keputusan seringkali tidak maksimal dalam menghasilkan keputusan-keputusan strategis. Akibatnya persoalan aktual lembaga

* Dosen tetap STAI Badrus Sholeh Kediri 
pendidikan yang dihadapi tidak dapat terselesaikan secara maksimal.

Pengamatan dan penilaian yang dilakukan secara simultan terhadap lingkungan eksternal dan internal lembaga pendidikan memungkinkan para pengelola pendidikan mampu mengidentifikasi berbagai jenis peluang yang ada untuk dapat merumuskan dan mengimplementasikan berbagai rencana pendidikan secara berhasil. Rancangan yang bersifat menyeluruh ini dapat dilakukan melalui proses tindakan yang dikenal sebagai analisis lingkungan strategik.

\section{Pembahasan}

"Strategi" berasal dari bahasa latin, "stratos (pasukan) dan "agein" (memimpin). Strategi menjawab pertanyaan mengenai, apa yang ingin kita lakukan, organisasi seperti apa yang kita inginkan, dan kemana organisasi akan menuju. ${ }^{1}$ Strategik menurut pendapat Blocher dan Lin adalah The Development of a sustainable competitive posisition in which the firm's competitive provides continued success. ${ }^{2}$ Sedangkan menurut Yuwono dan Ikhsan biasanya dihubungkan dengan pendekatan manajemen yang integratif, mengedepankan secara bersama-sama seluruh elemen seperti planning, implementating, dan controlling dari strategi. ${ }^{3}$ Selanjutnya, menurut Ansoff, strategik adalah, " A Systematic approach to major and increasingly important responsibility of general management: to position and relate the firm to its

\footnotetext{
1 Syaiful Sagala, Manajemen Strategik dalam Peningkatan Mutu Pendidikan, (Bandung: Alfabeta, 2011), 128.

2 Blocher dan lin, Manajemen Biaya, Buku I, (Jakarta: Penerbit Salemba, 1999).

3 Yuwono dan Ichsan, Petunjuk Praktis Penyusunan Balanced Scorecard: Menuju Organisasi Yang berfokus Pada Strategi, (Jakarta: PT Gramedia Pustaka Utama, 2004), 11.
}

environment". ${ }^{4}$ Ia berpendapat, strategik adalah pendekatan sistematis bagi tanggung jawab manajemen, mengkondisikan organisasi ke posisi yang dipastikan mencapai tujuan dengan cara yang akan meyakinkan keberhasilan keberlanjutan, dan membuat sekolah menjamin format yang mengejutkan.

Dalam dunia pendidikan, menggunakan konsep strategik lebih mengefektifkan pengalokasian sumber daya yang ada dalam mencapai tujuan pendidikan. Dalam hal ini berarti menentukan tujuan strategik berarti memformulasikan hasil-hasil yang diharapkan dicapai secara menyeluruh selama satu periode.

Proses yang berperan penting dalam menentukan tujuan strategik dikembangkan oleh berbagai macam konfiguarsi kekuatan dari dalam dan luar. Seperti kepala sekolah, guru, asosiasi guru, stakeholders, peserta didik, orang tua peserta didik, suplier kebutuhan sekolah, pemerintah pusat dan propinsi, pemerintah kabupaten/ kota kemudian kelompok-kelompok sosial yang menaruh perhatian terhadap program sekolah.

Menurut Ansoff pendekatan strategik adalah menganalisis bagianbagian yang disebut "formulasi strategi. Proses ini disebut juga perencanaan strategi, yakni para manajer dalam merumuskan strategi secara bersamasama. Berikut pendekatan strategis tersebut: ${ }^{5}$

1. Memosisikan sekolah melalui perusahaan strategi perencanaan kemampuan (positioning of the firm through strategy and capability planning).

Sekolah menyusun perencanaan memosisikan diri sesuai kemampuan dan potensi yang dimiliki, dengan

\footnotetext{
${ }^{4}$ Ignor Ansoff \& H. McDonnell, Implanting Strategic Management, second edition, (Prentice Hall International (UK) Ltd, 1990).

5 Ignor Ansoff \& H. McDonnell, Implanting Strategic Management....
} 
upaya mengoptimalkan sumber daya sekolah untuk mencapai tujuan.

2. Real-time tanggapan isu-isu strategis yang dikeluarkan manajemen (realtime strategic response through issue management of resistance during strategic implementation).

Mampu merespon isu-isu strategis seperti manajemen berbasis sekolah, kurikulum 2013, pengajaran kontekstual, dan sebagainya dalam sekolah untuk meningkatkan mutu.

3. Manajemen yang sistematis selama implementasi (systematic management of resistance during strategic implementation).

Menekankan objektivitas, ilmiah, dan sistematis selama implementasi strategis, strategi sekolah disusun berdasarkan prinsip-prinsip objektivitas, ilmiah, dan sistematis buka berdasar kehendak pribadi kepala sekolah, tetapi kehendak bersama mengakomodasi kebutuhan publik. ${ }^{6}$

Dalam tahapan analisa strategis selain perumusan dan implementasi juga ada pengendalian dan evaluasi. Tahap pengendalian dan evaluasi pimpinan melakukan pengawasan dalam rangka mendorong kelancaran pelaksanaan kegiatan-kegiatan yang telah dilaksanakan. Pimpinan juga perlu mengetahui atau memonitor kemajuan kegiatan yang telah dilaksanakan. Berdasarkan hasil monitoring itu, jika diperlukan maka semua strategi yang telah diterapkan dapat dimodifikasi di masa depan karena faktor-faktor eksternal dan internal selalu berubah. Tiga macam aktivitas mendasar untuk mengevaluasi strategi yaitu a) meninjau faktor-faktor eksternal dan internal yang menjadi dasar strategi sekarang, b) mengukur prestasi, dan c) mengambil tindakan korektif. ${ }^{7}$

6 Syaiful Sagala, Manajemen Strategik dalam Peningkatan Mutu Pendidikan, ...129.

7 Syaiful Sagala, Manajemen Strategik dalam Peningkatan Mutu Pendidikan, ...131.
Sejalan dengan hal itu, Melcher dkk mengemukakan unsur strategik yang meliputi:

1. Scope, batasan dimana sebuah organisasi bergerak, mencakup penetapan yang akan dihasilkan, pelanggan yang harus dilayani, lokasi tempat beroperasi, dan keseluruhan faktor kompetitif bagi organisasi. Top manajemen menetapkan skop sebagai bagian dari formulasi strategi.

2. Specifications, standar untuk mengukur posisi strategis sebuah organisasi saat ini. Secara ringkas spesifikasi memberikan jawaban tuntas dari pertanyaan: "Bagaimana kita menyelesaikan" dan "Bagaimana kita dapat melakukannya di masa yang akan datang".

3. Deployment, adalah penyiapan alokasi dana, fasilitas, peralatan, dan sumberdaya manusia dalam sebuah organisasi. $^{8}$

Langkah-langkah Strategi:

Dalam hal-hal formulasi strategis seperti yang dikemukakan oleh Sharplin langkah-langkah formulasi strategi (Strategy formulation) yakni: ${ }^{9}$

1. Menetapkan misi suatu organisasi yang utuh dengan melibatkan pemilik, pelanggan, dan pegawai sebagai konstituen organisasi. ${ }^{10}$

2. Melakukan assessment lingkungan eksternal organisasi dengan memperhatikan kondisi yang sedang terjadi dan kemungkinan perubahan yang akan terjadi, termasuk juga perkembangan dan kemampuan organisasi serupa.

3. Menetapkan arah dan sasaran organisasi. Maksudnya, mempertegas arah dan sasaran organisasi. Arah dan sasaran hendaknya bersifat menentang dan dapat diraih. Oleh sebab itu, penentuan sasaran

\footnotetext{
${ }^{8}$ Ibid., 131.

9 Sharplin, Srategic Management, (New York: McGraw-Hill Book Company, 1985), 48.

10 Dalam hal ini, berbicara misi juga harus melihat kemampuan dan keadaan internal organisasi.
} 
hendaknya spesifik, dapat dihitung, terukur, dan sasaran yang telah ditetepkan maupun arah yang teleh ditentukan perlusegera dipilih strategi apa yang hendak dipakai.

Sedangkan langkah-langkah fase implementasi strategik (Strategy Implementation), adalah melakukan evaluasi strategik, dan mengontrol atau pengawasan strategik.

1. Penggerakan strategik dapat didinamiskan dengan memperhatikan struktur, kebijakan, dan komitmen sumberdaya. Lebih lengkapnya dalam strategi ini adalah memperhatikan penempatan dalam struktur organisasi, aplikasi motivasi menjadi menjadi kegiatan strategik, penggunaan dasar-dasar kekuatan dan politik.

2. Evaluasi strategik dengan penuh kedisiplinan untuk memastikan apakah implementasi sesuai dengan perencanaan yang telah disepakati. Tujuan utamanya ini adalah untuk memotinoring dan mengevaluasi perkembangan organisasi dalam mencapai tujuan atau sasaran dengan standar tertentu.

3. Melakukan kontrol strategi sebagai langkah sesuai yang terkait langsung dengan evaluasi dengan maksud memberikan koreksi atau bimbingan, hasil dari koreksi itu dapat diambil kebijakan selanjutnya. ${ }^{11}$

Lembaga Penididikan Agama yang akan penulis sajikan di sini hanya terbatas pada sekolah formal dan non formal atau bahkan perguruan tinggi Islam. Lembaga pendidikan ini nantinya akan mendidik dan memproduksi tenagatenaga pendidik untuk mengajar di lembaga pendidikan ataupun pemikirpemikir Islam.

Penyelenggaraan pendidikan Islam tentu tak bisa dilepaskan dari beberapa asas yang menjadi landasan: 1) normatif-

11 Syaiful Sagala, Manajemen Strategik dalam Peningkatan Mutu Pendidikan, ...132. teologis, 2) filosofis , 3) historik, 4) sosiologi.

1. Landasan Normatif-Teologis

Dilihat dari aspek ini, dokrin Islam pada dasarnya mengajarkan kepada pemeluknya untuk memasuki Islam secara kaffah (meyeluruh), sebagai lawan dari ber-Islam yang parsial (Q.S. Al-Baqarah: 208). Islam kaffah mengadung konsep terwadahinya berbagai aspek kehidupan dalam Islam. Bahkan Nabi Muhammad pun tiada lain hanyalah sebagai rahmat bagi sekalian alam. ${ }^{12}$

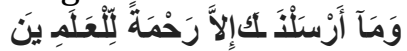

"Dan Tiadalah Kami mengutus kamu, melainkan untuk (menjadi) rahmat bagi semesta alam." (Al-Annbiya: 107)

Ajaran tersebut mengandung makna bahwa setiap muslim dituntut menjadi aktor beragama yang loyal, concern, dan commitment dalam menjaga dan memelihara nilai-nilai Islam dalam berbagai aspek kehidupan. Serta bersedia dan berdedikasi sesuai dengan minat, bakat, kemampuan, dan bidang keahliannya masing-masing dalam perspektif Islam. ${ }^{13}$

Dengan demikian, keberadaan penyelenggaraan Pendidikan Islam akan menjadi sarana, media dalam penyaluran visi tersebut di samping berimplikasi pada peningkatan kualitas iman, taqwa, bahkan iman (leader) bagi orang yang bertaqwa. ${ }^{14}$ (Q.S. Al-Furqan 25: 74). Taqwa ini terwujud dalam dua sikap, itba' syari'at Allah (mengikuti fundamental doctrin dan fundamantal values (yang terkandung dalam Alquran dan sunnah Rasulullah) serta itba' sunnatillah (mengikuti aturan-aturan

\footnotetext{
12 Muhaimin, Wacana Pengembangan Pendidikan Islam, (Surabaya: Pustaka Pelajar, 2003), 245.

13 Ibid., 246.

14 Ibid., 246.
} 
atau hukum-hukum Allah yang berlaku di alam semesta). ${ }^{15}$

2. Landasan Filisofis

Dilihat dari asepek filosofis, jika paradigma pendidikan Islam adalah upaya pengembangan pandangan hidup Islami, yang diwujudkan dalam sikap hidup dan dimanifestasikan dalam keterampilan hidup sehari-hari, maka perkembangan ilmu pengetahuan dan teknologi akan bertolak pada pandangan teosentris , dimana konsep antoposentris merupakan bagian esensial dari teosentris. Karena itu proses dan produk pencarian, penelitian dan eksistensi, serta pemanfaatan dalam kehidupan, merupakan realisasi dari misi kekhalifahan dan pengabdiannya kepada Allah di dunia dalam mencari ridla-Nya dalam kehidupan $u$ khrawi. ${ }^{16}$

Pandangan seperti itu akan berimplikasi pada model kurikulum atau program pendidikan dan proses belajar-mengajar yang dikembangkan. Tidak hanya menekankan pada penguasaan ilmu agama Islam tetapi juga menekankan bagaimana ilmu pengetahuan dan teknologi serta seni menerangkan berbagai problem yang

15 Ibid. (itba' syari'at Allah diwujudkan dengan 1) membaca dan memahami ajaran dan nilai-nilai mendasar dalam Al-Quran dan As-sunnah, 2) berusaha menghayati samil memosisikan diri sebagai pelaku ajaran Islam yang loyal, di samping menjadi pemikir, penalar, dan pengkaji, 3) memiliki komitmen yang tingi pada ajaran Islam, dan 4) berdedikasi dalam penegakan ajaran Islam yang rahmatan li al-'alamin. Sedangkan sikap itba' sunnatillah ditandai dengan senantiasa 5) membaca dan memahami fenomena alam, fisik, psikhis, fenomena sosio-historis, dan fenomena lainnya, 6) memosisikan sebagai pengamat, pengaji, peneliti, sehingga memiliki daya analisis tajam, kritis, dinamis, dalam memahami fenomena yang ada di sekitar, 7) senantiasa berusaha membangun kepekaan intelektual serta epekaan informasi, dan 8) kematangan profesionalisme dalam bakat, kemempuan, dan minat tertentu.

16 Ibid., 247. dihadapi kaum muslimin dalam kehidupan keseharian. ${ }^{17}$

3. Landasan Historis

Dilihat dari aspek historis, secara garis besar sejarah Islam menurut Harun Nasution (1995), dapat dibagi menjadi tiga periode. 1) periode klasik (650-1250 M), 2) periode pertengahan (1250-1800 M), 3 ) periode modern (1800-sekarang). Dalam realitas sejarahnya, periode klasik menggambarkan kejayaan, keemasan, dan kemajuan dunia Islam. Periode pertengahan menggambarkan kemunduran, sedangkan periode modern menggambarkan masa kebangkitan dunia Islam. ${ }^{18}$

Dengan menyimak pengalaman historis tersebut, maka pengembangan berbagai program studi dan kurikulum dalam penyelenggaraan pendidikan Islam berusaha dan menangkap ibrah serta pengembangan nilai-nilai, sikap dan cara berpikir dan berperilaku ulama (ilmuwan) pada periode klasik tersebut.

Maka dengan demikian, ujung tombak dari perencanaan strategik dalam penyelenggaraan pendidikan Islam yang diwujudkan melalui renstra pun, sudah semestinya bertolak pada visi tersebut. Dimana penyelenggaraan pendidikan Islam ataupun rencana strategik yang disusun dapat termuat dalam organisasi perangkat pendidikan (ada kurikulum dll), sehingga diharapkan mampu menghasilkan ulama yang bersikap rasional dan profesional, berpandangan luas, berbudi pekerti luhur, pengetahuannya tidak terbatas pada "ilmu keagamaan" saja tetapi juga mencakup ilmu pengetahuan umum, serta mampu berdiri sendiri (mandiri). ${ }^{19}$

\footnotetext{
17 Ibid., 249.

18 Ibid., $249 .$.

19 Muhaimin, Wacana Pengembangan Pendidikan Islam.... 251.
} 
4. Sosiologis

Sebagai contoh adalah penyelenggaraaan pendidikan Islam di sekolah/ madrasah. Sebagai sekolah umum yang bercirikan khas Islam, maka madrasah dituntut untuk memilki kualifikasi yang sama dengan sekolah umum baik dari segi tenaga kependidikannya, kurikulum, dan sebaginya. ${ }^{20}$

Sebagai sekolah yang berciri khas Islam maka madrasah mengembangkan: 1) mata pelajaran keagamaan yang dijabarkan dari pendidikan agama Islam, yaitu: AlQuaran, Hadits, Akidah, Akhlak, Fiqh, Sejarah Kebudayaan Islam, Bahasa Arab, dan 2) suasana keagamaan yang berupa: suasana kehidupan madrasah yang agamis, adanya sarana ibadah, penggunaan metode pendekatan yang agamis, kualifikasi guru yang harus beragama Islam dan berakhlak mulia. Dengan demikian, madrasah sebenarnya hendak memenuhi tiga komponen, 1) sebagai wahana untuk membina ruh, 2) memperkokoh keberadaan Madrasah sederajat dengan sistem sekolah, 3) berusaha merespon tuntutan masa depan. ${ }^{21}$

Analisis lingkungan, analisis SWOT, analisis stakeholder dalam tujuan dan harapan merupakan faktor-faktor kunci dari manajemen strategis, maksudnya ia merupakan faktor pembuka yang berperan pertama kali dari proses-proses manajemen strategi selanjutnya.

Analisis lingkungan adalah penilaian lingkungan secara menyeluruh dan akurat, baik lingkungan eksternal maupun internal.

Analisis lingkungan eksternal memiliki beberapa tahapan,

1. Scanning, memepelajari seluruh segmen dalam lingkungan pendidikan pada rencana penyelenggaraan Pendidikan Islam.

2. Monitoring, mengamati perubahan.
3. Forecasting, melakukan prediksi. ${ }^{22}$

4. Assessing, menentukan pengaruh perubahan lingkungan.

Analisis eksternal ini memiliki cakupan analisis terhadap kondisi yang melingkupi organisasi: politik, ekonomi, sosbud, teknologi, cakupan geografis \& konstelasi industri.

Selanjutnya, analisis faktor-faktor lingkungan, terutama lingkungan internal harus memalui tahapan fungsional, yakni pendekatan kesiswaan, keuangan, pendidikan, dan pengajaran, serta sumberdaya manusia. Pendekatan tersebut diwujudkan dalam:

1. Manajemen sumber daya manusia.

2. Manajemen kerumahtanggaan termasuk keuangan.

3. Manajemen pendidikan dan pengajaran

4. Manajemen komunikasi/ sosialisasi

5. Manajemen pelayanan

6. Manajemen administrasi

7. Manajemen sistem informasi

8. Penelitian dan pengembangan.

Dalam pelaksanaan analisis lingkungan internal tersebut, diperlukan pula teknik rantai nilai, yaitu melalui tahapan:

1. Aktivitas utama (primary avtivities). Yakni aktivitas yang terlibat dalam penciptaan phisik, program pengajaran, program kegiatan, dan lain-lain.

2. Aktivitas pendukung (supporting activities). Yakni aktivitas pelengkap dari aktivitas utama. Yakni keberadaan SDM, teknologi, dukungan administrasi,dan lain-lain.

Tujuan dari teknik rantai nilai ini adalah mengupayakan langkah-langkah yang dilakukan dapat dilakukan dengan memilih aktivitas yang memilki biaya terendah dan dapat mengubah nilai. Hasil dari analisi lingkungan internal dan eksternal ini dapat dilihat dari:
1. Melalui
proses
mempelajari lingkungan eksternal, lembaga

\footnotetext{
20 Ibid., 252.

${ }^{21}$ Ibid., 253.
}

22 Muhaimin, Wacana Pengembangan Pendidikan Islam....253. 
pendidikan mengidentifikasi apa yang mungkin mereka pilih untuk dikerjakan.

2. Melalui proses mempelajari lingkungan internal, lembaga pendidikan Islam dapat menentukan apa yang bisa mereka kerjakan. ${ }^{23}$

Salah satu instrumen analisis lingkungan internal dan eksternal adalah analisis SWOT. Analisis ini menyediakan para pengambil keputusan organisasi akan informasi yang dapat menyediakan dasar dan pertimbangan dalam pengambilan keputusan dan tindakan. Jika keputusan tersebut diterapkan secara efektif, maka akan memungkinkan sekolah mencapai tujuannya. ${ }^{24}$

Boseman menyebutkan:

1. Kekuatan adalah kemampuan internal sebuah organisasi yang memajukan tujuan organisasi.

2. Kelemahan adalah kebalikan, mereka membatasi penyelesaian tujuantujuan organisasi.

3. Peluang adalah keadaan, kejadian atau situasi eksternal yang menawarkan perubahan organisasi untuk mencapai atau melampaui tujuannya.

4. Tantangan atau hambatan adalah lawan dari peluang. Hambatan adalah kekuatan, faktor-faktor atau situasi eksternal yang mungkin secara potensial menciptakan masalah, kerusakan organisasi, atau membahayakan kemampuan unt mencapai tujuan. ${ }^{25}$

Dengan demikian, analisis SWOT dalam hal ini adalah indentifikasi beberapa faktor secara sistematis untuk merumuskan strategi perusahaan. Analisis ini didasarkan pada logika yang dapat memaksimalkan kekuatan (Strenghts) dan peluang (Opportunities), namun secara bersamaan dapat

23 Muhaimin, Wacana Pengembangan Pendidikan Islam......253.

24 Syaiful Sagala, Manajemen Strategik Dalam Peningkatan Mutu Pendidikan,...141

25 G. Boseman and A. Phatak, A Strategic

Managament: text and case, New York: Willey Sons Corp, 1989). meminimalkan kelemahan (Weaknesses) dan ancaman (Threats).

Selanjutnya hal yang tidak kalah pentingnya dalam analisis lingkungan adalah analisis stakeholder. Analisis ini merupakan instrumen yang sangat penting untuk memahami konteks sosial dan kelembagaan dari satu kegiatan program/ proyek. Instrumen ini digunakan untuk mengidentifikasi minat, kepentingan, dan pengaruh para stakeholder terhadap kegiatan program/ proyek yang sedang berjalan.

Berdasarkan uraian mengenai konsep analisis lingkungan strategik di atas disimpulkan karakteristik analisis lingkungan strategik adalah:

1. Analisis lingkungan strategik diwujudkan dalam bentuk perencanaan berskala besar, dalam arti mencakup kepentingan seluruh komponen organisasi. Hasil rumusan rencana ini biasanya dituangkan dalam bentuk rencana-rencana organisasi secara hierarkis, yakni: rencana strategis (renstra), rencana operasional (renop), program, dan kegiatan.

2. Rencana strategik berorientasi ke masa depan (misal 10 tahun ke atas),

3. Visi dan misi organisasi menjadi acuan dalam penyusunan rencana strategis.

4. Adanya keterlibatan pimpinan puncak dalam penyusunan rencana strategis.

5. Hasil rumusan rencana strategis diimplementasikan melalui fungsi manajemen.

Di dalam strategic planning terdapat proses memutuskan bagaimana menempatkan strategi-strategi ke dalam praktek. Maka sebelum itu, strategistrategi pun harus dirumuskan berdasar visi-misi, identifikasi kebutuhan, identifikasi pilihan-pilihan kebijakan mendasar, analisis kekuatan (Strenghts) dan peluang (Opportunitie) yang ada dalam analisi SWOT, hingga mengidentifikasi minat, kepentingan, dan pengaruh para stakeholder terhadap 
kegiatan program / proyek yang sedang berjalan. Baru kemudian, setelah pertimbangan tersebut, strategi planning yang tujuannya agar organisasi mampu melihat secara objektif kondisi internal eksternal dapat terlaksana. Sehingga organisasi dapat mengantisipasi perubahan lingkungan eksternal.

Pada dasarnya penyelenggaraan pendidikan Islam dalam praktek analisis lingkungan strategik ini memiliki konsep yang sama. Hanya saja dalam perumusan visi, misi, maupun analisis lingkungannya, tentu dibedakan. Jika penyelenggaraan pendidikan umum sasaran stakeholdernya lebih pada masyarakat secara luas, maka sasaran stakeholder penyelenggaraan pendidikan Islam lebih pada masyarakat muslim. Namun tidak menutup kemungkinan filantropi dari nonmuslimpun juga turut berbaur dalam sumbangsih pendidikan, terutama masalah finansial.

\section{Kesimpulan}

Pengamatan dan penilaian yang dilakukan secara simultan terhadap lingkungan eksternal dan internal lembaga pendidikan memungkinkan para pengelola pendidikan mampu mengidentifikasi berbagai jenis peluang untuk merumuskan dan mengimplementasikan rencana pendidikan. Rancangan yang bersifat menyeluruh dapat dilakukan melalui proses tindakan yang dikenal sebagai manajemen strategik.

Pada dasarnya penyelenggaraan pendidikan Islam dalam praktek manajemen strategis ini memiliki konsep yang sama. Hanya saja dalam perumusan vbisi, misi, maupun analisis lingkungannya, tentu dibedakan. Jika penyelenggaraan pendidikan umum sasaran stakeholdernya lebih pada masyarakat secara luas, maka sasaran stakeholder penyelenggaraan pendidikan Islam lebih pada masyarakat muslim. Namun tidak menutup kemungkinan filantropi dari nonmuslimpun juga turut berbaur dalam sumbangsih pendidikan, terutama masalah finansial.

\section{Bibliography}

Blocher lin, Manajemen Biaya, Buku I, (Jakarta: Penerbit Salemba, 1999).

G. Boseman and A. Phatak, A Strategic Managament: text and case, New York: Willey Sons Corp, 1989).

Ignor Ansoff \& H. McDonnell, Implanting Strategic Management, second edition, (Prentice Hall International (UK) Ltd, 1990).

Muhaimin, Wacana Pengembangan Pendidikan Islam, (Surabaya: Pustaka Pelajar, 2003).

Sharplin, Srategic Management, (New York: McGraw-Hill Book Company, 1985).

Syaiful Sagala, Manajemen Strategik dalam Peningkatan Mutu Pendidikan, (Bandung: Alfabeta, 2011).

Yuwono dan Ichsan, Petunjuk Praktis Penyusunan Balanced Scorecard: Menuju Organisasi Yang berfokus Pada Strategi, (Jakarta: PT Gramedia Pustaka Utama, 2004) 